\title{
Gene Mutation
}

National Cancer Institute

\section{Source}

National Cancer Institute. Gene Mutation. NCI Thesaurus. Code C18093.

The result of any gain, loss or alteration of the sequences comprising a gene, including all sequences transcribed into RNA. 